\title{
Scanning electron microscope study of dinospores of Amyloodinium cf. ocellatum, a pathogenic dinoflagellate parasite of marine fish, and comments on its relationship to the Peridiniales
}

\author{
Jan H. Landsberg, Karen A. Steidinger, Barbara A. Blakesley, Roy L. Zondervan \\ Florida Marine Research Institute, Florida Department of Environmental Protection, 100 Eighth Avenue Southeast, \\ St. Petersburg, Florida 33701-5095, USA
}

\begin{abstract}
Trophonts of a parasitic dinoflagellate were obtained from the gills of feral and cultured red drum Sciaenops ocellatus and aquarium-housed sebae clownfish Amphiprion clarkii, imperator Pomacanthus imperator, mandarin goby Pterosynchiropus splendidus and flame angelfish Centropyge loriculus. After incubation of tomonts, dinospores were studied by scanning electron microscopy. Dinospores have a plate pattern and tabulation of $\mathrm{Po}, \mathrm{Cp}, \mathrm{x}, 4^{\prime}, 1 \mathrm{a}, 7^{\prime \prime}, 6$ to 8 ? $\mathrm{C}$, ?s, 5"', $2^{\prime \prime \prime \prime}$, which are similar to that of the free-living Peridiniales. The parasite is tentatively identified as Amyloodinium cf. ocellatum. Most descriptions of parasitic dinoflagellates rely only on the morphology of the trophont. However, despite the fact that some past studies have questioned the validity of using dinospores in making taxonomic classifications because of their plastic and unstable morphological characteristics, dinospore characterization is critical. Traditionally, dinospores of parasitic dinoflagellates have been described as unarmored (naked) and have been considered to have gymnodinioid, gyrodinioid or cochlodinioid forms. Ultrastructural fixation techniques used for $A$. cf. ocellatum revealed the presence of thin plates arranged in. Kofoidian series. Such plates could be more prevalent in other dinoflagellate species than has been previously indicated, and existing taxonomic-classification schemes may need to be emended. Dinospores of other parasitic dinoflagellates should be reevaluated for the presence of similar diagnostic characteristics.
\end{abstract}

KEY WORDS: Parasite - Dinoflagellate Amyloodinium - Fish Peridiniales C Classification

\section{INTRODUCTION}

The Florida Department of Environmental Protection's (FDEP) Florida Marine Research Institute (FMRI) is conducting a long-term research program to determine the feasibility of increasing depleted feral stocks of red drum Sciaenops ocellatus (L.) by releasing cultured fish [raised at the Stock Enhancement Research Facility (SERF) at Palmetto, Florida, USA] into the wild. Since 1988, Amyloodinium sp. infestations have occurred in red drum broodstock and fingerlings in culture tanks. In closed-tank systems, infestation levels can build up rapidly and become lethal in a few days. Such infestations caused heavy mortalities initially, but because of successful management and treatment strategies to prevent and control this parasite (Vermeer et al. unpubl.), extensive mortalities now rarely occur. We have also recently determined that fish mortality in a $500 \mathrm{l}$ marine home aquarium was associated with Amyloodinium cf. ocellatum (Landsberg et al. in press). A. ocellatum is a nonspecific, marine fish ectoparasite (Brown 1934, Brown \& Hovasse 1946). There are numerous reports of its incidence and pathogenicity in mariculture and aquarium systems (Lawler 1977a, b, 1979, 1980, Paperna \& Baudin-Laurencin 1979, Ghittino et al. 1980, Paperna 1980, Baticados \& Quinitio 1984, Barbaro \& Francescon 1985, Aiello \& D'Alba 1986). The life cycle, development and morphology of $A$. ocellatum have been described (Brown 1931, 1934, Nigrelli 1936, Brown \& Hovasse 1946, Cheung et al. 
1981). The life cycle consists of 3 stages: a trophont that feeds while attached to skin and gill surfaces, an encysted tomont that develops after the trophont detaches from the fish, and motile dinospores that are released after the tomont divides. Each tomont can produce up to 256 dinospores, each of which has the potential to infect a new host and develop into a trophont (Brown \& Hovasse 1946). Dinospore production and infectivity occur over a broad range of temperatures $\left(16\right.$ to $\left.30^{\circ} \mathrm{C}\right)$ and salinities (10 to $60 \mathrm{ppt}$ ) (Paperna 1984).

Typically, trophonts are found on fish after heavy mortalities in culture (Paperna 1980, Noga et al. 1991) or in the wild (Lawler 1980, Alvarez-Pellitero et al. 1993, Overstreet 1993) and are usually reported as Amyloodinium ocellatum. Some recent studies have suggested that there may be more than 1 species or strain of Amyloodinium (Lom \& Lawler 1973, Lawler 1980, Noga et al. 1991), yet few attempts have been made to differentiate between forms by studying the surface structure of the dinospore using scanning electron microscopy (SEM) (Cheung et al. 1978, Cheung et al. 1981). SEM evaluation of the surface structure of the theca of flagellated (motile) stages, including plates if present, is a normal procedure in the systematic study of free-living or symbiotic dinoflagellates (Dodge \& Steidinger 1979 , Dodge 1987). Until recently, however, the ultrastructure of the trophont (dominant vegetative stage) has been emphasized in the classification of parasitic dinoflagellates (Lom \& Lawler 1973, Lom 1981, Lom \& Schubert 1983, McLean \& Nielsen 1989, McLean \& Galt 1990, Mills \& McLean 1991, Lom et al. 1993). Landsberg et al. (in press) presented a preliminary description of the thecal plate pattern and tabulation of the dinospore of A. cf. ocellatum isolated from parasitized fish in a marine home aquarium. The present communication further describes the dinospore morphology of $A$. cf. ocellatum, confirms its natural occurrence in red drum, questions its relationship to the form described as $A$. ocellatum (Brown \& Hovasse 1946), and comments on its relationship with the Peridiniales. We also emphasize that SEM analysis of motile stages should be used in classifying parasitic dinoflagellates.

\section{MATERIALS AND METHODS}

Red drum juveniles raised in culture at SERF were obtained in February and March 1993. Juvenile feral red drum were obtained from Bishop's Harbor, in Manatee County, Florida, in January and June 1993 and monthly from Murray Creek, in Volusia County, Florida, from March through June 1993. Fish obtained on several occasions from a marine home aquarium (St. Petersburg, Florida) from April through June 1993 included clownfish Amphiprion ocellaris, sebae clownfish Amphiprion clarkii, mandarin goby Pterosynchiropus splendidus, imperator Pomacanthus imperator, flame angelfish Centropyge loriculus, Pacific blue tang Paracanthurus hepatus, achilles tang Acanthurus achilles, cleaner wrasse Labroides dimidiatus, half black angel Centropyge vroliki and blue damsels Chrysiptera sp. The fish were examined for parasites, and viable trophonts were obtained from red drum, mandarin goby, imperator, sebae clownfish and flame angelfish. Tomonts were cultured according to methods previously described (Landsberg et al. in press) and were checked daily for division until dinospores emerged. Dinospores from individual tomonts were chemically fixed by different methods so that,we could determine the most appropriate technique for analyzing thecal plate pattern and tabulation. The fixation methods tested included combinations of either $1 \%$ or $2 \%$ osmium tetroxide buffered in 0.1 or $0.2 \mathrm{M}$ sodium cacodylate. The initial $\mathrm{pH}$ of the sea water was 7.9 to 8.3. We also tested a cold $\left(4^{\circ} \mathrm{C}\right)$ combination fixative composed of $9.4 \%$ glutaraldehyde (GTA) and $2 \%$ osmium tetroxide buffered with sodium cacodylate (pH 7.3) [modified from Steidinger et al. (1989)]. The osmolality (isotonic to hyperosmotic, $\Delta 62 \mathrm{Mosm}$ ) and length of fixation time (15 to $60 \mathrm{~min})$ of this latter fixative were varied. Fixed specimens were criticalpoint dried, sputter-coated with gold-palladium, and examined on a Cambridge Instruments/Leica Stereoscan 240 Scanning Electron Microscope.

\section{RESULTS}

All fish species examined were infested with trophonts of Amyloodinium sp. Mean standard lengths and size ranges of fish parasitized by $A$. cf. ocellatum (confirmed by SEM study of dinospores) are given in Table 1. Incu-

Table 1 Mean standard lengths and size ranges of fish parasitired by Amyloodinium cf. ocellatum. SERF: Stock Enhancement Research Facility (Palmetto, FL, USA); BH: Bishop's Harbor (FL, USA); VC: Volusia County (FL, USA)

\begin{tabular}{|lccr|}
\hline Species & $\begin{array}{c}\text { Mean standard } \\
\text { length }(\mathrm{cm})\end{array}$ & $\begin{array}{c}\text { Range } \\
(\mathrm{cm})\end{array}$ & $\mathrm{n}$ \\
\hline Red drum & & & \\
SERF (Feb) & 5.4 & $4.5-6.7$ & 30 \\
SERF (Mar) & 10.6 & $8.7-12.3$ & 8 \\
BH & 9.1 & $5.6-12.7$ & 9 \\
VC & 8.3 & $5.4-11.6$ & 19 \\
Sebae clownfish & 3.5 & - & 1 \\
Mandarin goby & 3.8 & - & 1 \\
Imperator & 6.4 & - & 1 \\
Flame angelfish & 5.1 & - & 1 \\
\hline
\end{tabular}


Table 2. Amyloodinium cf. ocellatum. Tomont incubation temperatures $\left({ }^{\circ} \mathrm{C}\right)$, length of incubation time to dinospore emergence, and life span of dinospores

\begin{tabular}{|lccc|}
\hline Species & $\begin{array}{c}\text { Incubation } \\
\text { temperature }\end{array}$ & $\begin{array}{c}\text { Incubation } \\
\text { time (d) }\end{array}$ & $\begin{array}{c}\text { Dinospore } \\
\text { life span (d) }\end{array}$ \\
Red drum & & & \\
SERF & $18-27$ & $2-20$ & $2-14$ \\
BH & $20-28$ & $3-5$ & $2-10$ \\
VC & $18-31$ & $2-7$ & $2-6$ \\
Sebae clowntish & 24 & $2-3$ & $5-6$ \\
Mandarin goby & 21 & 2 & $1-14$ \\
Imperator & $21-24$ & $2-5$ & 6 \\
Flame angelfish & 21 & 2 & $?$ \\
& & & \\
\hline
\end{tabular}

bation temperature of tomonts, length of time to dinospore emergence, and dinospore life span are shown in Table 2 . Of the fixation methods tried, the most effective one for determining plate structure of the dinospore of A. cf. ocellatum was the GTA/osmium tetroxide combination cold fix (Fig. 1). The other fixation methods used resulted in 'blown' dinospores in which at least 2 outer membranes were totally 'stripped', leaving a smooth surface (Fig. 2), or they resulted in distortion, leaving a thick nodular surface (Fig. 3).

The Amyloodinium cf. ocellatum dinospore is a small, anteroposteriorly compressed, thinly armored peridinioid type, having an epitheca that is slightly shorter than the hypotheca (mean epitheca length $=2.7 \pm 0.2 \mu \mathrm{m}$, mean hypotheca length $=3.3 \pm 0.6 \mu \mathrm{m}, \mathrm{n}=9$ ) (Fig. 4) The dinospore plate pattern and tabulation of $A$. cf ocellatum isolated from red drum, sebae clownfish and mandarin goby were the same. Dinospores were $6.1 \pm 0.8 \mu \mathrm{m}$ in length, $11.7 \pm 0.5 \mu \mathrm{m}$ in width, and $11.1 \pm 1.2 \mu \mathrm{m}$ in depth $(n=11)$. Of the several hundred individual dinospores evaluated, all were found to have a plate pattern and tabulation conforming to that of the free-living Peridiniales. The plate formula is $\mathrm{Po}$, $\mathrm{Cp}, \mathrm{x}, 4^{\prime}, 1 \mathrm{a}, 7^{\prime \prime}, 6$ to 8 ? $\mathrm{c}$, ?s, 5'", $2^{\prime \prime \prime \prime}$ (Figs. 5 to 8 ). The plate formula varied in some specimens by having 8 precingulars (Fig. 9) or 6 postcingulars (Fig. 10). The cell is 'hamburger-shaped', with a deeply excavated cingulum that is displaced 1 to $1.5 \times$ (Fig. 4). In apical view, the right side appears deeper than the left because of the extension of the 1 ' beyond the cingular margin of the 1 " plate. The 1 ' is in contact with the $x$ plate of the apical pore complex (APC; Figs. 5 \& 7) and lies directly over the sulcus (Fig. 11); it is typically rhomboid (Fig. 9), or has a postmedian horizontal suture (Figs. 5 \& 7). The $\mathrm{Po}$ is elongate and is positioned under the rims of the $2^{\prime}$ and $4^{\prime}$; it abuts the $3^{\prime}$ (Figs. 5, $9 \& 11$ ). The closing or cover plate of the APC is elongate, irregular in outline, and the anterior margin appears crenulate or dentate (Fig. 12). The $x$ plate is directly below the Po and in direct contact with 1' (Figs. 5,9\& 11). Plates 1', 2', 4', and the $7^{\prime \prime}$ (or $8^{\prime \prime}$ ) overlap the $1^{\prime}$, which is sometimes slightly displaced to the left (Fig. 11). The hypotheca has a typical peridinioid plate pattern (Figs. 6, 8 \& 10).

The thecal complex appears rugose and nodular to vermiculate, and although there are cytoplasmic trichocysts in the dinospore (Landsberg et al, unpubl.), there are no obvious external trichocyst pores even at $\times 34196$ (Fig. 12). The dinospore surface has numerous nodules of various sizes (Fig. 13), and the plate sutures are slightly raised (Figs. 1, $5 \& 6$ ). The sulcus is narrow distally and is about 3 times as wide proximally (Fig. 4). The widest part is excavated between the 1 "' and 5"' plates. This excavation houses the peduncle and a rhizoid-like complex that appears to protrude from under the plate(s) in the right sulcal area (Figs. 6 $\& 14)$. The longitudinal flagellum is located below the peduncle (Fig. 14) and is 20 to $25 \mu \mathrm{m}$ long (Fig. 15). It has a prominent longitudinal groove that separates 2 components (Fig. 16), of which 1 sometimes extends approximately $5 \mu \mathrm{m}$ beyond the other (Fig. 15). The transverse flagellum is located in the cingulum, and fine hairs (Figs. 1, 4, 5 \& 9) along its length attach it to the cell surface.

\section{DISCUSSION}

Based on their morphology, dinospores of Amyloodinium ocellatum were described as naked gymnodinioid types of dinoflagellate (Brown 1934, Nigrelli 1936, Lom 1981). Recently, the original description of the dinospore morphology of $A$. ocellatum has been questioned. Brown (1934) and Brown \& Hovasse (1946) described the dinospore of $A$. ocellatum isolated from the Zoological Aquarium in London as being elongate and having the epicone smaller than the hypocone. Nigrelli (1936) reported $A$. ocellatum on marine fish in the New York Aquarium and described the dinospore as having an epicone that was slightly smaller than the hypocone. Brown (1934) and Brown \& Hovasse (1946) reported the presence of a stigma in the hypocone, but Nigrelli (1936) described a stigma in the epicone. Dinospore measurements were $12.5 \times 9.0 \mu \mathrm{m}$ or $15.0 \times$ $14.0 \mu \mathrm{m}$ (Brown 1934) or 12.0 long $\times 8.0 \mu \mathrm{m}$ wide (Nigrelli 1936). Lawler (1980) found that the shape of A. ocellatum dinospores isolated from the Gulf of Mexico differed from that of the earlier descriptions. Dinospores described in his paper were more anteroposteriorly flattened, had a red stigma in the hypocone, had an epicone shorter than the hypocone, had 1 flagellum with an undulating beat in a very distinct girdle, had a longer longitudinal flagellum, had a body 11.6 to 15.4 long $\times 10.4$ to $14.5 \mu \mathrm{m}$ wide, and could survive in a free-living stage for at least $15 \mathrm{~d}$. Trophont 

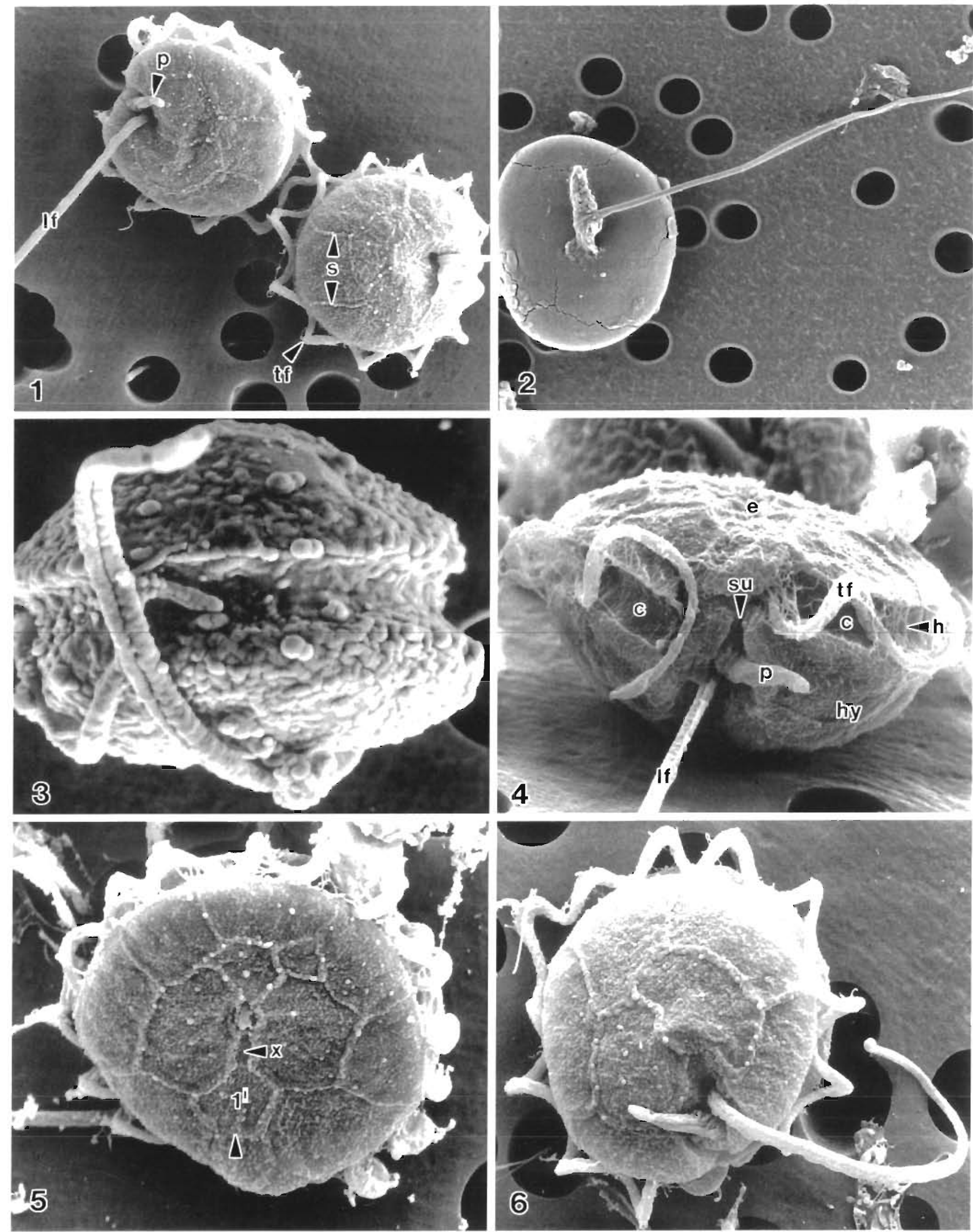
Figs. 1 to 6. Amyloodinium cf. ocellatum. Scanning electron microscope micrographs. Fig. 1 Hypothecal view of 2 dinospores showing longitudinal flagellum (lf), peduncle $(\mathrm{p})$, sutures (s), and transverse flagellum (tf); $\times 3890$. Fig. 2. 'Blown' dinospore with smooth surface; $\times 2190$. Fig. 3. Poorly fixed dinospore with thick nodular surface and flagellum; $\times 8960$. Fig. 4 . Ventral view of dinospore showing displacement of cingulum (c), sulcus (su), longitudinal flagellum (lf), peduncle (p), transverse flagellum (tf) with attached hairs (h), epitheca (e), and hypotheca (hy); $\times 7760$. Fig. 5. Epithecal view of dinospore showing 1 st apical plate (1'), $x$ plate $(x)$, and postmedian horizontal suture (arrow); $\times 6580$. Fig. 6 . Hypothecal view of dinospore; $\times 5830$

and tomont morphological characteristics were similar to those given in the original descriptions of $A$. ocellatum. Bower et al. (1987) also commented on the pronounced anteroposterior flattening of dinospores of the $A$. ocellatum (DC-1) strain isolated from clownfish (Amphiprion ocellaris), whereas the other life-cycle stages conformed to the original descriptions. Noga et al. (1991) mentioned apparent differences in the dinospore structure of A. ocellatum isolated from a natural outbreak of amyloodiniosis in hybrid striped bass in North Carolina, and they discussed the potential existence of different strains or species. In that report, dinospores were described as anteroposteriorly flattened and were 8.0 long $\times 13.8 \mu \mathrm{m}$ wide. These recent descriptions seem to conform more closely to the dinospore structure discussed herein than to the original description.

From the time of its original description using light microscopy until its recent description using electron microscopy, the structure of the dinospore of $A$. ocellatum had still not been confirmed. Cheung et al. (1981) published scanning electron micrographs of dinospores having a smooth surface and remarked on the poor quality of the pictures. We believe that poor fixation and preparation methods may have precluded the detection of the exact structure and that in fact, their micrographs showed disrupted dinospores (Cheung et al. 1981) such as those in Fig. 2. The question of the relationship between $A$. ocellatum and $A$. cf. ocellatum remains. The original London Aquarium isolates of $A$. ocellatum were obtained from coral reef fish from Bermuda and the East Indies (Brown 1934). A. ocellatum from the New York Aquarium was found on fish from the East Indies as well as from 15 local host species of naturally infested fish from Sandy Hook Bay, New Jersey, USA. The A. ocellatum dinospores of Lawler (1980) and Bower et al. (1987) seem to be more closely related to $A$. cf. ocellatum than to the organism originally described as $A$. ocellatum. Type material of $A$. ocellatum is lacking. If specimens can again be obtained from Sandy Hook Bay, then the relationships of these variously reported species might be clarified.

The presence of a peduncle and an associated rhizoid-like complex in a motile dinospore stage is reported here for the first time. A stomopode and rhizoid complex are known in the trophont stage of some parasitic dinoflagellates (Lom \& Lawler 1973). Rhizoids anchor the trophont to the host's epithelium, and the stomopode injects lytic substances into the prey (Lom \& Lawler 1973). Presumably, the peduncle of Amyloodinium cf. ocellatum extends to form the stomopode after attachment. This can be seen by com-

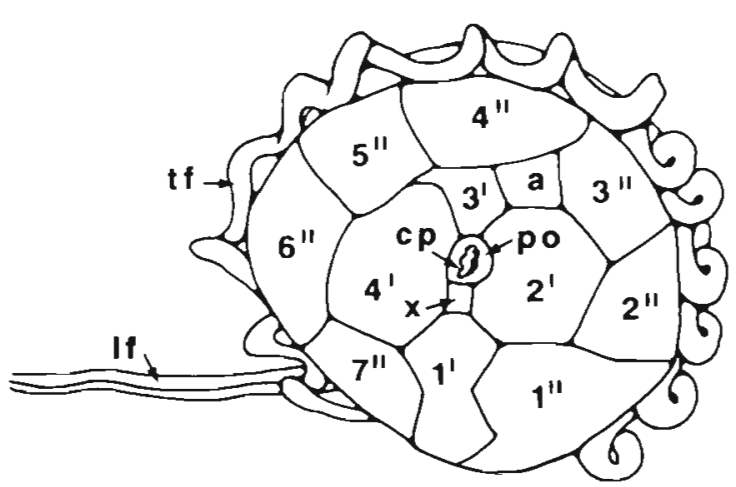

7

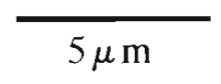

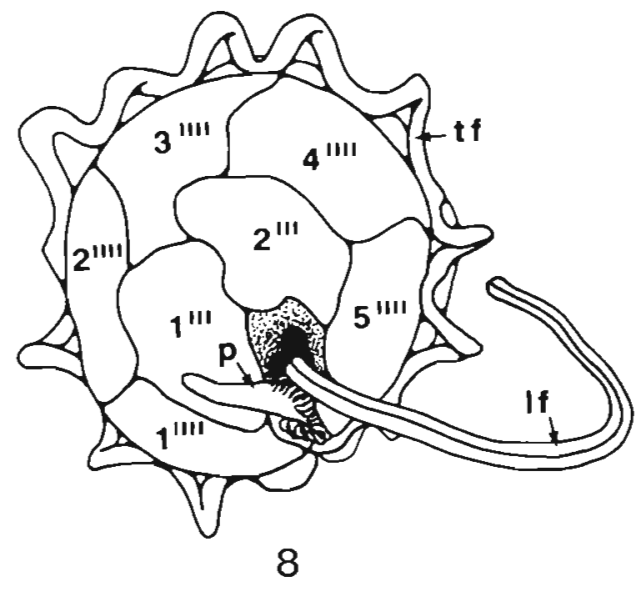

Figs. 7 \& 8. Amyloodinium cf. ocellatum. Schematic drawings of micrographs of Figs. 5 \& 6. Fig. 7. Epithecal plate tabulation showing apical pore ( $\mathrm{Po}$ ), closing plate $(\mathrm{Cp})$, and canal plate ( $\mathrm{x}$ ), 1st to 4 th apical plates (1' to 4 '), anterior intercalary (a), 1 st to 7 th precingular plates (1" to 7 "), transverse flagellum (ff), and longitudinal flagellum (lf). Fig. 8. Hypothecal plate tabulation showing 1 st and 2nd antapical plates (1'", $\left.2^{\prime \prime \prime}\right)$, 1st to 5 th postcingular plates (1'"' to $5^{\prime \prime \prime \prime), ~ p e d u n c l e ~(p), ~ l o n g i t u d i n a l ~ f l a g e l l u m ~(l f), ~ a n d ~}$ transverse flagellum (tf) 

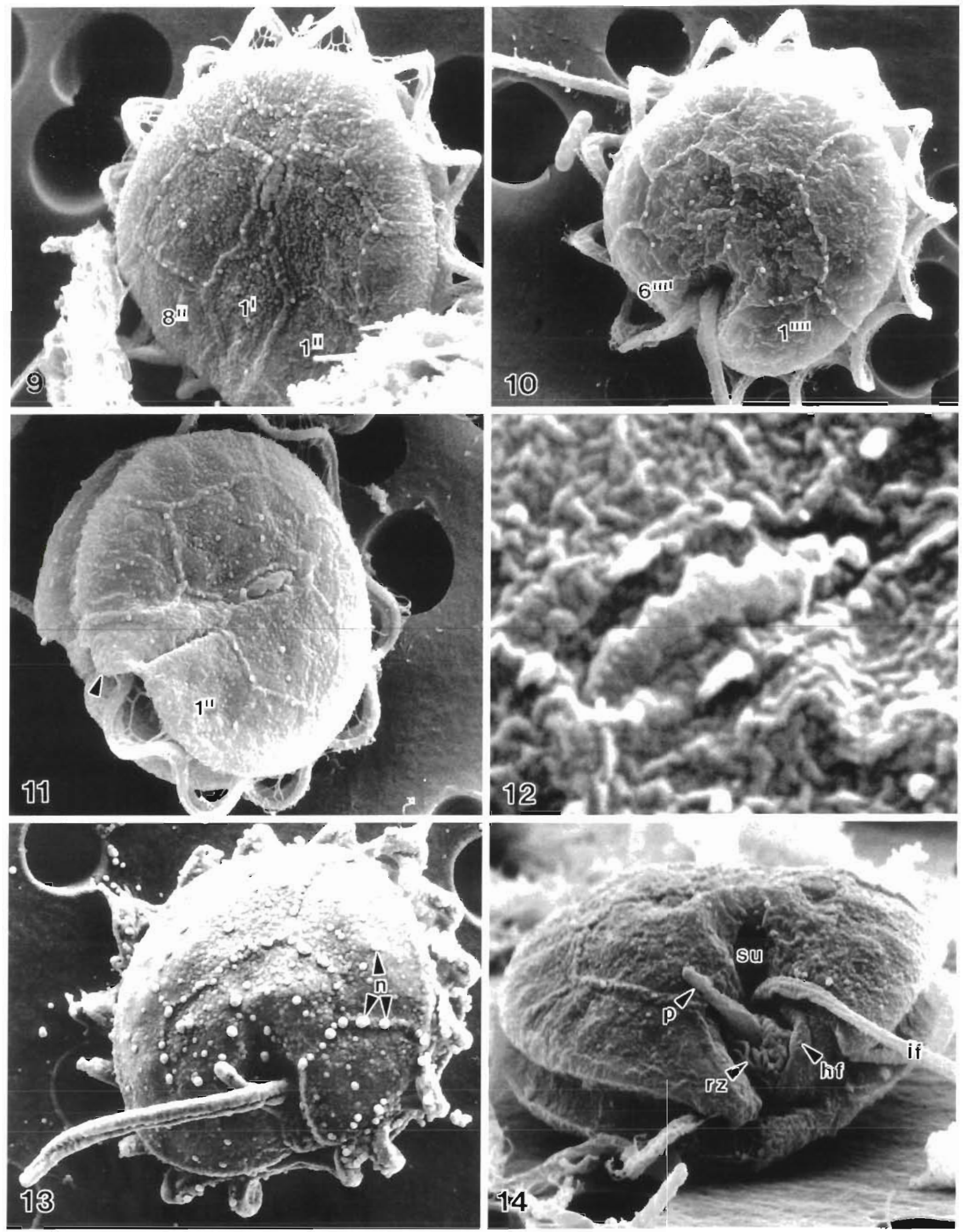
Figs. 9 to 14. Amyloodinium cf. ocellatum. Scanning electron microscope micrographs. Fig. 9. Variation of epithecal tabulation showing the 1 st and 8 th precingular plates $\left(1 " \& 8^{\prime \prime}\right)$ and 1 st apical plate $(1)^{\prime} \times 6600$. Fig. 10. Variation of hypothecal tabulation showing the 1 st and 6 th postcingular plates $\left(1^{\prime \prime \prime} \& 6^{\prime \prime \prime}\right)_{;} \times 5550$. Fig. 11. Epithecal/ventral view of dinospore showing extension of the 1st apical plate (arrow) beyond the cingular margin of the first precingular plate (1"); $\times 6270$. Fig. 12. Apical pore complex showing ridged closing plate; $\times 34200$. Fig. 13 . Dinospore surface with numerous, variably sized nodules $(n)$; $\times 5730$ Fig. 14. Hypothecal/ventral view showing peduncle (p), rhizoid-like (rz) complex, hood-lıke flange (hf), deep sulcal groove (su), and longitudinal flagellum $(\mathrm{lf}) ; \times 8310$

paring the transmission electron microscope (TEM) micrographs of the microtubular basket in both dinospores and trophonts (Landsberg et al. unpubl.) with those of the stomopode in Amyloodinium sp. trophonts (Lom \& Lawler 1973). A peduncle is usually associated with heterotrophic or mixotrophic forms of nutrition in dinoflagellates, and the microtubular basket complex of phagotrophs is well documented (Schnepf \& Elbrächter 1992). The grooved longitudinal flagellum (Figs. $15 \& 16$ ) of $A$. cf. ocellatum has not previously been recorded in parasitic dinoflagellates. The accessory portion may consist of a paraxial rod similar to the ventral flagellum of Oxyrrhis marina (Dodge \& Crawford 1971) and to the longitudinal flagellum of some other dinoflagellates. For example, spiral packing material (or a paraxial rod equivalent) has been described from TEM micrographs in free-living Amphidinium cryophilum (Wilcox et al. 1982), Ceratium tripos (Maruyama 1982) and Gymnodinium sp. (Leadbeater \& Dodge 1967). In addition, SEM micrographs of other dinoflagellates such as Peridinium cinctum f. westii (Berman \& Roth 1979), Gymnodinium splendens (Herman \& Sweeney 1977), Gymnodinium sp. (Roberts 1986) and Symbiodinium spp. (Trench \& Blank 1987) seem to indicate grooved, 2portioned longitudinal flagella.

Traditionally, the dinospore of parasitic dinoflagellates has been described as unarmored (naked) and as having gymnodinioid, gyrodinioid or cochlodinioid forms that are important for parasite classification (Chatton 1938). Some studies have questioned the need to use dinospore structure as a taxonomic criterion, since it is too plastic and unstable for classification (Cachon \& Cachon 1987). We believe that char-
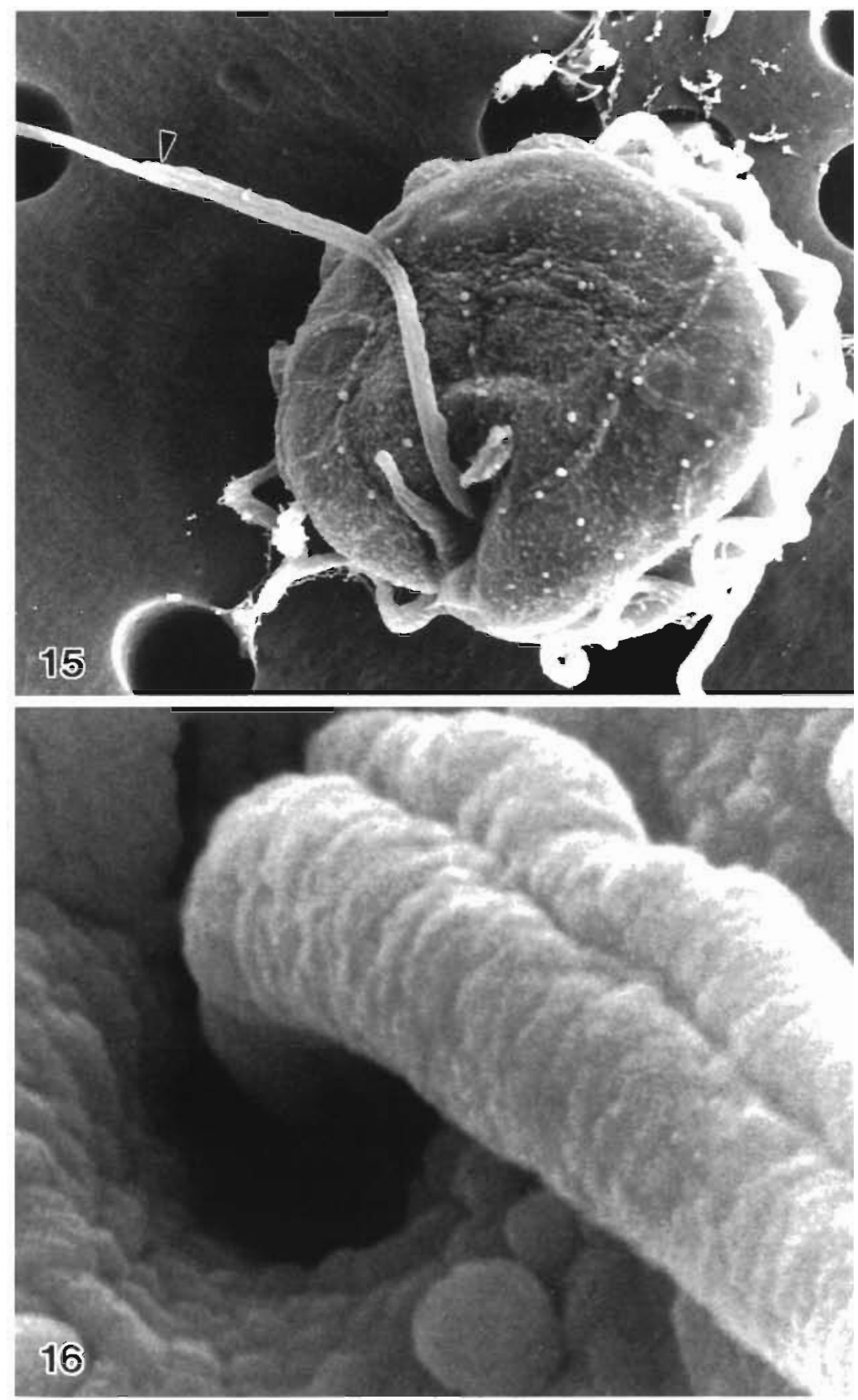

Figs. 15 \& 16. Amyloodinium cf. ocellatum. Scanning electron microscope micrographs. Fig. 15. Hypothecal view of dinospore showing tapering longitudinal flagellum (arrow); $\times 5840$. Fig. 16. High magnification of grooved structure of longitudinal flagellum; $\times 64430$ 
acterization of parasitic dinoflagellates from morphological study of the dinospore is critical. Only a few parasitic dinoflagellates having an armored dinospore have been identified, e.g. Protoodinium poucheti (Cachon \& Cachon 1971a), but even in these, the plate tabulation and patterns have not been described. Ultrastructural studies of Oodinium fritillariae, $P$. poucheti, $O$. dogieli and Amyloodinium sp trophonts have shown that there are thecal plates in the thecal vesicles (= periplast alveoli or amphiesmal vesicles) (Cachon \& Cachon 1971b, Lom \& Lawler 1973), which would indicate that plates should be detectable in the dinospore stage. Gonocytes of the endoparasite Haplozoon axiothellae, found in the polychaete Axiothella rubrocincta, also contain thin plates in thecal vesicles (Siebert \& West 1974). TEM micrographs of the parasitic phagotroph Paulsenella sp. show diagonal sutures, yet these features were not discussed (Schnepf ct al. 1985). Our preliminary studies suggest that the dinospore is an extremely useful stage for classificatory purposes. Dinospore and trophont morphology and ultrastructure should be used together to classify parasitic dinoflagellates. The acceptance of these classificatory criteria has very important taxonomic implications. By judging the morphology of these dinospores solely at the light level, it would be easy to incorrectly describe them as unarmored and related to the Gymnodiniales. However, improved ultrastructural fixation techniques for Amyloodinium cf. ocellatum revealed the presence of thin plates arranged in Kofoidian series and having a tabulation typical of the Peridiniales (Loeblich 1982). Further study of the cingular and sulcal areas for total number of plates and arrangement is necessary for this species to fully characterize the pattern and tabulation. Use of refined fixation techniques may show that plates in Kofoidian series could be more prevalent than previously thought in both parasitic and free-living dinoflagellates. Dinospores of other parasitic dinoflagellates should be scrutinized for similar diagnostic characters. The relationship and affinities of $A$. cf. ocellatum to other parasitic genera classified in the Blastodiniales, as well as to free-living genera classified in the Peridiniales, require further study. Differences in life cycles, trophic strategies and behavioral adaptations of these 2 orders currently determine placement into separate taxa (Loeblich 1982).

This type of evaluation is probably also applicable to some other small, free-living, and symbiotic 'gymnodinioid' dinoflagellates that have been previously classified as unarmored types. For example, Gymnodinium estuariale appears to have an apical pore complex typical of armored species (Gardiner et al. 1989), and motile cells of Gyrodinium lebouriae apparently have thecal plates (Lee 1977). In addition, the symbiotic
Symbiodinium spp. have thin thecal plates in vesicles (Trench \& Blank 1987) and a definite plate tabulation has been described in S. microadriaticum (Loeblich \& Sherley 1979), yet they are still classified in the Gymnodiniales (Trench \& Blank 1987). Actually, Symbiodinium spp. seem to be transitional between unarmored and armored dinoflagellates in that they have an apical groove (= acrobase) rather than an APC (as in armored species), about 62 plates, and a 2 -tiered plate series like some Woloszynskia spp. Further studies are needed to clarify the evolutionary relationships among free-living, symbiotic, and parasitic dinoflagellates and to allow characterization of their structure in relation to trophic adaptations.

Acknowledgements. The tesearch described in this study was supported by funding from the U.S. Fish and Wildife Service, Federal Aid in Sport Fish Restoration, Project F-44 and the National. Science Foundation Grant No. DIR-8914885. We thank Carmen Andress for the use of antibiotic mixes; Earnest Truby for discussions on fixation; Noretta Perry for photographic assistance; Ruth Reese, Greg Vermeer, Judy Leiby, and Jim Quinn for their comments on the marluscript; and Llyn French for drawings.

\section{LITERATURE CITED}

Aiello, P., D'Alba, A. (1986). Amyloodinium ocellatum infestation in yellowtail, Seriola dumerili, intensively reared in Sicily, Italy. Bull. Eur. Ass. Fish Pathol. 6: 110-111

Alvarez-Pellitero, P., Sitja-Bobadilla, A., Franco-Sierra, A. (1993). Protozoan parasites of wild and cultured sea bass. Dicentrarchus labrax (L.), from the Mediterranean area. Aquacult. Fish. Manage. 24: 101-1.08

Barbaro, A., Francescon, A. (1985). Parassitosi da Amyloodinium ocellatum (Dinophyceae) su larve di Sparus aurata allevate in un impianto di riproduzione artificiale. Oebalia 11: 745-752

Baticados, M. C. L., Quinitio, G. F. (1984). Occurrence and pathology of an Amyloodinium-like protozoan parasite on gills of grey mullet, Mugil cephalus. Helgoländer Meeresunters. 37: 595-601

Berman, T., Roth, I. L. (1979). The flagella of Peridinium cinctum $\mathrm{f}$. westii: in situ fixation and observation by scanning electron microscopy. Phycologia 18: 307-311

Bower, C. E., Turner, D. T., Biever, R. C. (1987). A standardized method of propagating the marine tish parasite, Amyloodinium ocellatum. J. Parasitol. 73: 85-88

Brown, E. M. (1931). Note on new species of dinoflagellate from the gills and epidermis of marine fishes. Proc. Zool. Soc. Lond. 1931. 345-346

Brown, E. M. (1934). On Oodinium ocellatum Brown, a parasitic dinoflagellate causing epidemic disease in marine fish. Proc. Zool. Soc. Lond. 1934: 583-607

Brown, E. M., Hovasse, R. (1946). Amyloodinium ocellatum Brown, a peridinian parasite on marine fishes. A complementary study. Proc. Zool. Soc. Lond. 116: 33-46

Cachon, J., Cachon, M. (1971a). Protoodinium chattoni Hovasse manifestations ultrastructurales des rapports entre le péridinien et la méduse-hôte: fixation, phagocytose. Arch. Protistenkd. 113: 293-305 
Cachon, J., Cachon. M. (1971b). Ultrastructures du genre Oodinium Chatton. Différenciations cellulaires en rapport avec la vie parasitaire. Protistologica 7: 153-169

Cachon, J., Cachon, M. (1987). Parasitic dinoflagellates. In: Taylor, F. J. R. (ed.) The biology of dinoflagellates. Blackwell Scientific Publications, Oxford, p. 571-610

Chatton, E. (1938). Titres et travaux scientifiques (1906-1937). Sottano, Sète

Cheung, P. J., Nigrelli, R. F., Ruggieri, G. D. (1978). Scanning electron microscopic observation on the various stages of the life cycle of Oodinium ocellatum Brown. Trans. Am. Microsc. Soc. 98: 157

Cheung, P. J., Nigrelli, R. F., Ruggieri, G. D. (1981). Development of Oodinium ocellatum (Dinoflagellida): a scanning electron microscopic study. Trans. Am. Microsc. Soc. 100: $415-420$

Dodge, J. D. (1987). Dinoflagellate ultrastructure and complex organelles. In: Taylor, F. J. R. (ed.) The biology of dinoflagellates. Blackwell Scientific Publications, Oxford, p. 92-119

Dodge, J. D., Crawford, R. M. (1971). Fine structure of the dinoflagellate Oxyrrhis marina II. The flagellar system. Protistologica 7: 399-409

Dodge, J. D., Steidinger, K. A. (1979). Dinophyceae: introduction and bibliography. In: Rosowski, J. R., Parker, B. C. (eds.) Selected papers in phycology. Phycological Society of America, Lawrence, KS, p. 691-697

Gardiner, W. E., Rushing, A. E., Dawes, C. J. (1989). Uitrastructural abservations of Gyrodinium estuariale (Dinophyceae). J. Phycol. 25: 178-183

Ghittino, P., Bignami, S., Annbali, A., Boni, L. (1980). Prima segnalazione di grave Oodiniasi in branzini (Dicentrarchus labrax) allevati intessivamete in aqua salmastra. Riv. ital. Piscic. lttiopat. 15: 122-127

Herman, E., Sweeney, B. M. (1977). Scanning electron microscope observation of the flagellar structure of Gymnodinium splendens. Phycologia 16: 115-118

Landsberg, J. H., Steidinger, K. A., Blakesley, B. A. (in press) Fish-killing dinoflagellates in a tropical marine aquarium. In: Proceedings of the Sixth International Conference on Toxic Marine Phytoplankton, Nantes, France, 18-22 October, 1993. IFREMER, Brest

Lawler, A. R. (1977a). The parasitic dinoflagellate Amyloodinium ocellatum in marine aquaria. Drum and Croaker 17: $17-20$

Lawler, A. R. (1977b). Dinoflagellate (Amyloodinium) infestation of pompano. In: Sindermann, C. J. (ed.) Disease diagnosis and control in North American aquaculture. Elsevier Scientific Publications, Amsterdam, p. 257-264

Lawler, A. R. (1979). North American fishes reported as hosts of Amyloodinium ocellatum (Brown 1931). Drum and Croaker 19: 8-14

Lawler, A. R. (1980). Studies on Amyloodinium ocellatum (Dinoflagellata) in Mississippi Sound: natural and experimental hosts. Gulf Res. Rep. 6: 403-413

Leadbeater, B., Dodge, J. D. (1967). An electron microscope study of dinoflagellate flagella. J. gen. Microbiol. 46: 305-314

Lee, R. E. (1977). Saprophytic and phagocytic isolates of the colourless heterotrophic dinoflagellate Gyrodinium lebouriae Herdman. J. mar biol. Ass. U.K. 57: 303-315

Loeblich, A. R. III (1982). Dinophyceae. In: Parker, S. P. (ed.) Synopsis and classification of living organisms. McGrawHill, New York, p. 101-115

Loeblich, A. R., Sherley, J. L. (1979). Observations on the theca of the motile phase of free-living and symbiotic isolates of Zooxanthella microadriatica (Freudenthal) comb. nov. J. mar. biol. Ass. U.K. 59: 195-205
Lom, J. (1981). Fish invadıng dinoflagellates: a synopsis of existing and newly proposed genera. Folia parasitol. 28: $3-11$

Lom, J., Lawler, A. R. (1973). An ultrastructural study on the mode of attachment in dinoflagellates invading gills of Cyprinodontidae. Protistologica 9: 293-309

Lom, J., Rohde, K., Dyková, 1. (1993). Crepidoodinıum australe n. sp., an ectocommensal dınoflagellate from the gills of Sillago ciliata, an estuarine fish from the New South Wales coast of Australia. Dis aquat. Org. 15:63-72

Lom, J., Schubert, G. (1983). Ultrastructural study of Piscinoodinium pillulare (Schaperclaus 1954) Lom 1981 with special emphasis on its attachment to the host. J. Fish Dis. 6: $411-428$

Maruyama, $T$ (1982). Fine structure of the longitudinal flagellum in Ceratium tripos, a marine dinoflagellate. J. Cell Sci. 58: 109-123

Mclean, N., Galt, C. P. (1990). Apodinium floodi n sp., a dinoflagellate (Dinoflagellata: Apodinidae) ectoparasitic on Oikopleura labradoriensis (Urochordata: Larvacea). Dis. aquat. Org. 9: 213-219

McLean, N., Nielsen, C. (1989). Oodinium jordani n. sp., a dinoflagellate (Dinoflagellata: Oodinidae) ectoparasitic on Sagitta elegans (Chaetognatha). Dis. aquat. Org. 7: 61-66

Mills, C. E., McLean, N. (1991). Ectoparasitism by a dinoflagellate (Dinoflagellata: Oodinidae) on 5 ctenophores (Ctenophora) and a hydromedusa (Cnidaria). Dis. aquat. Org. 10: 211-216

Nigrelli, R. F. (1936). The morphology, cytology and life history of Oodinium ocellatum (Brown), a dinoflagellate parasite on marine fishes. Zoologica 21. 129-164

Noga, E. J., Smith, S. A., Landsberg, J. H. (1991). Amyloodiniosis in cultured hybrid striped bass (Morone saxatilis $\times M$. chrysops in North Carolina. J. aquat. Anim. Health 3: $294-297$

Overstreet, R. M. (1993). Parasitic diseases of fishes and their relationship with toxicants and other environmental factors. In: Couch, J. A., Fournie, J. W. (eds.) Pathobiology of marine and estuarine organisms. CRC Press, Boca Raton, FL, p. 111-156

Paperna, 1. (1980). Amyloodinium ocellatum (Brown 1931) (Dinoflagellida) infestations in cultured marine fish at Eilat, Red Sea: epizootiology and pathology. J. Fish Dis. 3: $363-372$

Paperna, I. (1984). Reproduction cycle and tolerance to temperature and salinity of Amyloodinium ocellatum (Brown 1931) (Dinoflagellida). Ann. Parasitol. Hum. Comp. 59 $7-30$

Paperna, I., Baudin-Laurencin, F. (1979). Parasitic infections of sea bass, Dicentrarchus labrax and gilthead seabream, Sparus aurata in mariculture facilities in France. Aquaculture 38: 1-18

Roberts, K. E. (1986). The flagellar apparatus of Gymnodinium sp. (Dinophyceae). J. Phycol. 22: 456-466

Schnepf, E., Deichgraber, G., Drebes, G. (1985). Food uptake and the fine structure of the dinophyte Paulsenella sp., an ectoparasite of marine diatoms. Protoplasma 124: 188-204

Schnepf, E., Elbrächter, M. (1992). Nutritional strategies in dinoflagellates. A review with emphasis on cell biological aspects. Eur. J. Protistol. 28: 3-24

Siebert, A. E., West, J A. (1974). The fine structure of the parasitic dinoflagellate Haplozoon axiothellae. Protoplasma 81. 17-35

Steidinger, K. A., Babcock, C., Mahmoudi, B., Tomas, C., Truby, E. (1989). Conservative taxonomic characters in toxic dinoflagellate species identification. In: Okaichi, $T$., Anderson, D. M., Nemoto, T. (eds.) Red tides: biology, 
environmental science, and toxicology. Elsevier Scientific Publishing Company, Amsterdam, p. 285-288

Trench, R. K., Blank, R. J. (1987). Symbiodinium microadriaticum Freudenthal, S goreauii sp. nov., S. kawagutii sp. nov. and S. pilosum sp. nov.: gymnodınioid dinoflagellate

Responsible Subject Editor: W. Körting, Hannover, Germany symbionts of marine invertebrates. J. Phycol. 23: 469-481 Wilcox, L. W., Wedemayer, G. J., Graham, L. E. (1982). Amphidinum cryophilum sp. nov. (Dinophyceae) a new freshwater dinoflagellate. 2. Ultrastructure. J. Phycol. 18: $18-30$

Manuscript first received: November 28, 1993 Revised version accepted: March 20, 1994 